\title{
Creationism down under
}

Sir-Tony Thulborn is to be congratulated on his exposure of the Creation Science Foundation in Queensland (Nature 9 May, p.89) and will be pleased to know that the Australian APE (Australian Association for the Protection of Evolution) is not entirely alone.

The Institute of Biology in Australia (IBA), which is a branch of the Institute of Biology and on the road to total independence, has already challenged creationists in a major symposium, "In defence of science - A response to creationism", held in Sydney with an audience of more than 200 people on 9 March. The meeting was sponsored by IBA jointly with the Linnean Society of New South Wales, the Royal Zoological Society of New South Wales and the Australian Museum Society. Speakers successfully countered persistent (and ill-informed) questioning by creationists, some of whom freely admitted to teaching creationism unofficially in science classes at all levels, in schools in New South Wales, thus confirming Thulborn's suspicions.

The proceedings were videotaped by staff from the Commonwealth (Australian) Department of Education. A short film will be released to schools soon. The papers and discussion (edited by Dr Frank Burrows) will be published by the University of New South Wales as the first volume of a new series entitled Australian Studies in Biology.

The fight against creationism will be continued at the second annual general meeting of the institute in Brisbane on 5-7 July. A motion will be put affirming inter alia that creationism is not a science and thus has no place in any biology syllabus in Australian schools.

JOHN SKIDMORE

Institute of Biology in Australia,

Science Centre,

35-43 Clarence Street,

Sydney, NSW 2000, Australia

SIR-Michael Cavanaugh's implications in his article "Scientific creationism and rationality" (Nature 16 May, p.185) cast some doubts as to whether creationism can muster sufficient support from bona fide academics and especially from PhDs holding established positions in reputable scientific organizations. One of the main reasons for this state of affairs, of course, is that creationists are threatened by their own colleagues and by legal action by their own school boards and institutions if they do not keep a strictly low profile either publicly or in their own class rooms. Fear of loss of respect and prestige, not to mention endangering their own jobs, is what keeps highly qualified creationists in their ivory towers (even to the extent where they avoid open association with outspoken creationists). I speak from person- al experience and from the knowledge of what other creationists are going through.

School of Biological Sciences,

C. K. Pallaghy

La Trobe University,

Bundoora, Victoria, Australia

SIR-Having reread Genesis for the first time in several years, prompted by Cavanaugh (Nature 315,185; 1985) on creationism, I still fail to see the difference between creationism and evolutionism apart from the time-scale, which could easily be resolved by postulating that one theological day corresponds to a large number of millennia, in which case we are still waiting for the events of the eighth day. If we accept this approximation, then the only difference between evolutionism and creationism is the question of the catalyst.

As the hypothesis of the creationists is a supernatural force whose existence can be established only in the after-life, it would seem reasonable to withhold judgement until after death when the hypothesis will be confirmed or refuted. Given the many millennia which modern evolutionists would consider to correspond to a single creationist's day and the relatively short time since the creation of man, which marked the end of the sixth day and which was followed by a day of rest, it would seem likely that death for most of us alive today will be an earlier event than the creationist's eighth day.

Further speculation is futile, providing creationists will concede to the evolutionists that the theological day is indeed in excess of 24 worldly hours.

Department of Urology,

R. T. D. Oliver

London Hospital Medical College,

Whitechapel, London E1 1BB, UK.

\section{Jobs in Spain}

SIR-Recently, because of the large number of technical and academic professionals emigrating during the Franco years, King Juan Carlos let it be known that no Spaniard should ever again feel that he (or she) could not work in Spain. Unfortunately, the inertia of 40 years of scorning knowledge and its human heritage leaves the royal wish unheeded in the spheres which could do something about it.

During the Franco era and even afterwards, a small but steady stream of young Spaniards left Spain to do research or to benefit from higher education abroad. Many now wish to return. The national propaganda (words and wishes) wants them back; the system, however, is not willing. In Spain, positions at universities or research institutes are awarded by peculiar and primitive ritualized examinations called "oposiciones". In principle (and on paper), they are open to any Spa- niard. The reality is different; only Spaniards with a Spanish degree can apply. In short, a degree of any kind from a foreign university (regardless of its name or place) is not valid and the knowledge that accompanies it is questioned. Of course, the bureaucracy provides a simple way out: "convalidacion" (validation). One can apply to validate one's degree; what this involves varies and, in general, is inversely proportional to how many influential personalities the applicant knows.

It is a sad and deplorable situation, particularly in the euphoria of Spanish integration in Europe. The absurdity of the situation is clear from the fact that any Spaniard with a Spanish PhD can obtain a job in Europe or the United States, without any bureaucracy or any more questions than those related to the job; any Spaniard with a $\mathrm{PhD}$, from, say a US, English or German university has to fall into a "windmill battle" with Spanish academic authorities and thus is not eligible for a job in his/her own country.

It is important that these ancestral prejudices disappear. They are probably a consequence of the isolationism that has characterized the Iberian peninsula for centuries. The accession of Spain to the European Community attemps to break the barriers that extend above the Pyrenees. Let us hope that it breaks all barriers. AlFonso Martinez-Arias MRC Laboratory of Molecular Biology, Hills Road, Cambridge CB2 2QH, UK.

\section{Scientist arrested}

SIR - We have heard from scientists in Poland that their colleague, Zbigniew Gluza, has been arrested. Gluza, aged 33, was employed at the editorial board of the journal Informatics - the leading publication in the field in Poland-and is a member of the Polish Informatical Society. He was also a member of Solidarity.

Zbibniew Gluza has become a victim of the regime and an example of the planned programme of repression being suffered by Polish intellectuals.

During a random inspection in the street in Warsaw, the Polish milicja found some popular underground literature in Gluza's car. It should be pointed out that these underground bulletins play an important role in Poland, because official publications do not carry a genuine news digest-only officially edited reports which are usually distorted by ideology and its powerful instrument, censorship.

Letters of protest are being written to Polish embassies, consulates, cultural and scientific institutions. It is to be hoped that international groups and societies will add their weight to the protest. The efforts of private individuals will also be welcomed.

Peter GÄrdenfors

\section{Department of Philosophy,}

Lund University,

Kungshuset, Lundagard,

S-223 50 Lund, Sweden 